\title{
Challenge of Understanding Multichannel Customer Behavior in 21st Century: A Meta-analysis
}

\author{
Kim Soohyun · Ahn Insook \\ Dept. of Textiles, Merchandising \& Interiors, University of Georgia \\ Dept. of Fashion Design, Chungang University
}

\begin{abstract}
The purposes of this study are to provide comprehensive reviews on multichannel consumer behaviors published in peer-reviewed academic journals from 2005 to 2014, to develop a conceptual framework that demonstrates multichannel determinants such as psychographics, demographics, social influences, and situational factors on consumers' search and purchase behavior based on customers' profits or costs judgment, and to provide possible direction for future research in multichannel consumer behavior. Three steps were taken in the process of analyzing consumers' channel determinants presented in the 37 studies, and 12 most frequently used factors that appear in the studies were extracted. These factors include convenience, service, trust/risk, saving money, product knowledge, experience, efficacy/usefulness, involvement, shopping environment/situation factors, demographics, product types, and social influence. With 12 determinants of multichannel consumers' search and purchase behavior, a conceptual framework was proposed based on expectancy theory. The directions for future research were also discussed.
\end{abstract}

Key words : meta-analysis, multichannel, search and purchase behavior

\section{Introduction}

Multichannel retailing consists of selling products or services to consumers via more than one channel (Levy \& Weitz, 2009). Multichannel, or cross-channel, shopping is d efined as the patronage to more than one retail setting (Murphy, 2000; Scally, 2000).

There are two strategic options that multichannel retailers use. One option is operating channels as independent entities (order and receive or pick up at the same channel) ; and the other is integrating multiple channels, (cross

Corresponding author: Ahn Insook, Tel. +82-10-2281-6397, Fax. +82-31-676-9932

E-mail:corekim@cau.ac.kr

This research was supported by the Chungang University Research Grants in 2014. 
Kim Soohyun - Ahn Insook / Challenge of Understanding Multichannel Customer Behavior in 21st Century

channel movements of products or services, money, and information), but they need to have same pricing and positioning (Chatterjee, 2010a). Multichannel retailers, so-called brick-and-click retailers, and market customers use more than one channel or medium; this includes the Internet, catalogs, television, and traditional retail stores (Burt \& Sparks, 2003; Stone, Hobbs, \& Khaleeli, 2002) in traditional multichannel business. Because of advanced technology, smart phones and tablets are becoming more innovative, and the rate of consumer technology adoption is growing (Walker, 2011). This causes consumer behavior constantly to change. Mobile phones and tablets are used not only for communication, reading, mobile coupons, comparing prices, searching products, or checking ratings and reviews, but also for purchasing products or services. Therefore, the modern multichannel retailers, so-called brick click-and-touch retailers, serve customers using more than one channel or medium. These channels include the Internet, catalogs, kiosk, television, mobile phones, tablets, and traditional retail stores to retain customers, ensure satisfaction, increase sales.

Multichannel distribution has become the norm. Home Shopping Network (HSN), for example, started as a television home shopping company and became a multichannel retailer through acquisition of Cornerstone. Cornerstone distributes more than 300 million catalogs annually, operates online retail sites for all brands, and runs 11 retail and outlet stores ("General information", 2014). Similarly, Talbots originally marketed to their customers through catalogs and expanded their business to brick-and-mortar and online channels. Originally an online retailer, Threadless.com, became a multichannel retailer by selling their $T$-shirt products through vendors and operating one brick-and-mortar store. Likewise, traditional brick-and-mortar retailers such as Macy's and Urban Outfitters have become multichannel retailers utilizing both the Internet and catalogs.

Non-store sales increased 9.7\% between 2012 and 2014 to $\$ 447$ billion and increased $75 \%$ since 2005 in the United States (“U.S. Census", 2014). Electronic shopping and mail-order house sales increased 10.9\% between 2011 and 2012 to $\$ 323$ billion and increased $83.4 \%$ compared to sales in 2005 (“U.S. Census", 2014). According to IBM (2012), $15.6 \%$ of all online sessions on a retailer's site were initiated from a mobile device in the December 2011 holiday season, more than double the rate of $5.6 \%$ over this same period in 2010. Sales from mobile devices doubled, reaching $11 \%$ of online sales versus 5.5\% in December 2010. A commissioned consumer survey from more than 6,500 consumers in European countries examined the differences in attitudes toward online shopping consumers about their satisfaction, likes and dislikes, common frustrations, and spending habits related to online shopping, revealing fair differences in buying behaviors among the countries surveyed ("European consumer", 2010). Amazon's Price Check Application even allows customers to make sure a deal is real savings while shopping in physical retail stores (“Amazon app”, 2011).

The importance of understanding today's ever-connected and empowered customers' behavior cannot be overemphasized. Customers are adopting new technologies and are more comfortable interacting with retailers via a variety of touch points such as brick-and-mortars, catalogs, the Internet, call centers, e-mail, interactive TV, mobiles, kiosks, tablets, et cetera. As well as being pressured to expand to these 
complex channels, marketers are competing for limited customers (Walker, 2011). Satisfying the customers' needs and wants is not an easy task as their expectations and choices become ever greater. To satisfy and retain customers, retailers need to take steps to fully understand what motivates consumers, what they think, and how they behave. These steps make retailers build better channel development and manage consumers' channel choices effectively.

In this study, the researchers provide comprehensive reviews of studies of multichannel consumer behaviors published in peer-reviewed academic journals from 2005 to 2014. Secondly, this study proposes a conceptual framework that demonstrates multichannel determinants such as psychographics, demographics, social influences, and situational factors on consumers' search and purchase behavior based on customers' benefits or costs judgment. Finally, the researchers hope to provide possible future research directions in multichannel consumer behavior.

The present meta-analysis is organized as follows: methodology, including data collection, description, and a description of the analysis; proposed framework and findings; and the conclusion.

\section{Data Collection}

Computer databases (Ebsco, Web of Science, Google Scholar) were initially searched to identify appropriate researches done in multichannel retailing areas. Search terms included different combinations of multichannel, cross channel, retail, channel switch, consumer behavior, purchasing behavior, search behavior, and decision making. Data collection efforts also included a systematic search of academic journals within the timeframe of January 2005 to
March 2014. The next step in this data collection process involved a type of snowball sampling; references were listed by the obtained studies or by tracking citations using Web of Science. The identified papers were then evaluated for their appropriateness for inclusion in the study. Seventy-eight academic reviewed papers were collected. For this meta-analysis study, all papers that used secondary data or qualitative studies were eliminated. Out of the 38 studies selected for final stage, one study was eliminated because it used almost the same samples for another paper by the same authors. This resulted in a final sample of 37 papers.

\section{Description of Sample}

Out of 37 journal papers, more than half $(n=19)$ of the studies were done in the USA, 12 studies in Europe, and 5 studies in Asia. The most used product category is apparel including cosmetics and shoes $(n=19)$, financial and other services such as travel and mobile plans $(n=9)$, $\mathrm{CD}$ /audio ( $n=7)$, and consumer electronics $(n=6)$, followed by home furnishing, books, computer related products, and others. Twenty-five studies used more than 300 samples, and college students were used as the samples in 14 studies. For the multichannel settings, brick-and-mortar, the Internet, catalogs, and in-home shopping formats were utilized to analyze multichannel channel consumer behavior.

\section{Conceptual Framework for Multichannel Customer Behavior}

The study presented in Figure 1 shows a framework that exhibits the customers' purchasing decision process through consumers' perceived 
utilities of multichannel use, multichannel customers' search and purchase behaviors, and moderators, based on expectancy theory. Expectancy theory posits that an individual behaves or acts in a certain way because they link particular utilities or consequences to product or service attributes so that they select a specific behavior over other (Oliver, 1974; Rosenberg, 1956). Therefore, this study assumes that the customers choose certain channels for product or service search and purchase to achieve their goals with maximizing benefits and minimizing costs based on their perception of multichannel utilities. As shown in Figure 1, consumers' assessments of benefits and costs for using channels may influenced by their psychographics, demographics, social influences, and situational/ environmental factors. In addition, the conceptual model shows moderating factors on multichannel behavior. For example, suppose a customer needs an outfit for a special event. Then the customer may search information about price, promotion, design, and material through various channels. The customer may ask friends' opinions on the outfit he or she chose. The customer may place an online order for the outfit and purchase and pick it up at a designated store because he/she wants to feel and touch the product. Once the customers have a good experience with multichannel decision making, this may reinforce his/her perception of channel. This also causes the possibility of the use of the same channels for future purchases.

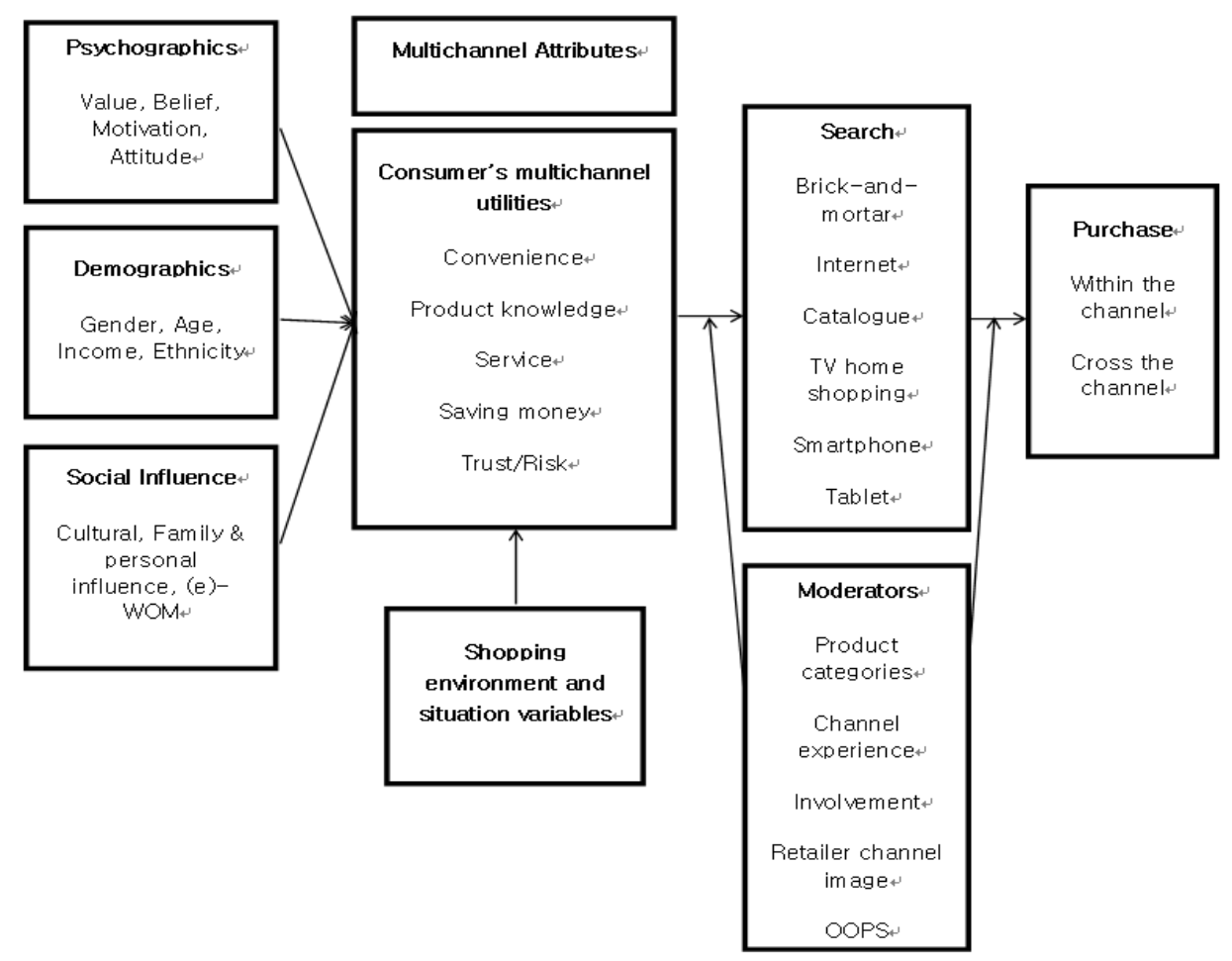

Figure 1. Conceptual Model of Multichannel Consumer Behavior 


\section{Understanding of Customer Behavior in Multichannel Environment}

Each channel has distinct advantages and drawbacks for different types of consumers during their purchasing process. Each channel may represent unique offers to meet customers' wants and needs and have comparative advantages in the multichannel environment (Kollmann, Kuckertz, \& Kayser, 2012). Customer perception of a channel drives their channel choice behavior, and may be influenced by how a customer learns/evaluates the channel choice. The importance of the different channel attributes for consumers' channel choices might differ across the stage of buying process, depending on the goals consumers pursue in each stage of the buying process (Frambach, Roest, \& Krishnan, 2007; Gefen, Benbasat, \& Pavlou, 2008). For example, consumers address on gathering accurate and relevant product or service information in the search stage (Carlson et al., 2008). In the purchasing stage, consumers may aim for buying the selected product at the lowest price (Hamilton, Chernev, \& Chernev, 2010) unless they are under time pressure.

\section{Data Analysis}

Three steps were taken in the process of analyzing consumers' channel determinants presented in the various studies. First, as shown in Table 1, the factors/determinants used $(n=$ 70) in the various studies were extracted from the text of the papers. Second, determinant descriptions as given in the papers were reviewed, and then concepts were re-sorted into fifteen categories. These were further condensed based on their logical relationship to the applicability to multichannel choice. For example, the fewer the risk factors involved with the product, delivery, and financing, the more trust may be elicited. Therefore, risk and trust factors were merged into one factor. This effort led to the twelve most-used factors that appear in the studies. These factors are convenience, product knowledge, service, product types, trust/risk, involvement, experience, saving money, shopping environment/situation factors, efficacy/usefulness, social influence, and demographics (See Table 2).

\section{Channel Determinants}

Choi and Park (2006) segmented multichannel customers into three groups: utilitarian shoppers, recreational shoppers, and apathetic shoppers. According to the research collected from Korean respondents (Choi \& Park, 2006), about $46 \%$ of the respondents were single-channel offline purchases and preferred both information search and purchase at offline channels. Thirty-six percent of the sample were inclined to search information online but purchase at offline channels. Single channel online purchasers (8.8\%) searched information and purchased online. Among multichannel shoppers, about nine percent of them tended to search offline and purchase online. Choi and Park (2006) argued that single-channel online purchasers were more likely to be economic- and recreation-oriented shoppers. Schröder and Zaharia's research (2008) on the purchasing behavior of 525 multichannel customers of a German multichannel retailer operating five channels found that $48.6 \%$ were one-channel offline shoppers and $32.6 \%$ were multichannel shoppers for grocery and bakery products. 
Kim Soohyun - Ahn Insook / Challenge of Understanding Multichannel Customer Behavior in 21st Century

Table 1. Factor Categorization

\begin{tabular}{|c|c|c|c|}
\hline Convenience & Product knowledge & Service & Product types \\
\hline $\begin{array}{l}\text { Accessibility } \\
\text { Around clock } \\
\text { Convenience } \\
\text { Distance } \\
\text { Energy } \\
\text { Immediate possession } \\
\text { Seeking flexibility } \\
\text { Time }\end{array}$ & $\begin{array}{l}\text { Assortment } \\
\text { Brochure quality } \\
\text { Information availability } \\
\text { Local store offering } \\
\text { Product quality } \\
\text { Touch \& feel } \\
\text { Touch \& try } \\
\text { Usefulness of information } \\
\text { Variety }\end{array}$ & $\begin{array}{l}\text { Agent } \\
\text { Better advice } \\
\text { OOPS } \\
\text { Service } \\
\text { Service complexity } \\
\text { Service quality } \\
\text { Social presence }\end{array}$ & $\begin{array}{l}\text { Experience goods } \\
\text { Search goods }\end{array}$ \\
\hline
\end{tabular}

\begin{tabular}{|c|c|c|c|}
\hline Trust/Risk & Involvement & Experience & Saving money \\
\hline $\begin{array}{l}\text { Confidentiality } \\
\text { Credit card ownership } \\
\text { Risk (product, delivery, } \\
\text { financial) } \\
\text { Security/privacy } \\
\text { Trust }\end{array}$ & $\begin{array}{l}\text { Channel involvement } \\
\text { Community attachment } \\
\text { Fashion innovativeness } \\
\text { Product involvement }\end{array}$ & $\begin{array}{l}\text { Experience } \\
\text { Frequency of } \\
\text { information search } \\
\text { Internet experience } \\
\text { Offline image } \\
\text { Offline influence } \\
\text { Vicarious experience }\end{array}$ & $\begin{array}{l}\text { Price } \\
\text { Negotiation possibility } \\
\text { Promotion } \\
\text { Switching cost }\end{array}$ \\
\hline
\end{tabular}

\begin{tabular}{|c|c|c|c|}
\hline $\begin{array}{l}\text { Shopping environment } \\
\text { / situation factors }\end{array}$ & Efficacy/Usefulness & Social influence & Demographics \\
\hline $\begin{array}{l}\text { Internet connectivity } \\
\text { Store atmosphere } \\
\text { Store design } \\
\text { Store quality } \\
\text { Time-of-day of purchase } \\
\text { Time pressure } \\
\text { Web quality }\end{array}$ & $\begin{array}{l}\text { Ease of use } \\
\text { Multichannel efficacy } \\
\text { Perceived efficacy of } \\
\text { sanction } \\
\text { Perceived usefulness } \\
\text { Self-affirmation needs of } \\
\text { expertise } \\
\text { Self-efficacy }\end{array}$ & $\begin{array}{l}\text { Clientele } \\
\text { Culture } \\
\text { Reference group } \\
\text { Normative belief } \\
\text { Subjective norm } \\
\text { WOM }\end{array}$ & $\begin{array}{l}\text { Age } \\
\text { Gender } \\
\text { Income } \\
\text { Job } \\
\text { Education } \\
\text { Urbanity }\end{array}$ \\
\hline
\end{tabular}


Journal of Fashion Business Vol.18, No.3

Table 2. Most Prominently Used Factors

\begin{tabular}{|c|c|c|c|c|}
\hline $\begin{array}{l}\text { Factor } \\
(\mathrm{N})\end{array}$ & "Convenience $(n=17)$ & Service $(n=13)$ & Trust/Risk $(n=13)$ & "Saving money $(\mathrm{n}=12)$ \\
\hline Reference & $\begin{array}{l}\text { Chatterjee, 2010a; } \\
\text { Chatterjee, 2010b; } \\
\text { Chiange \& Li, 2010; } \\
\text { Fernandez-Sabiote \& } \\
\text { Roman, 2012; } \\
\text { Frambach et al., } \\
\text { 2007; Gensler et al., } \\
\text { 2012; Heitz-Spahn, } \\
\text { 2013; Johnson et } \\
\text { al., 2006; Y. Kim, } \\
\text { Park, \& Pookulangara, } \\
\text { 2005; Kollmann, } \\
\text { Kuckertz, \& Kayser, } \\
\text { 2012; Lee \& Kim, } \\
\text { 2008; Lu \& Rucker, } \\
\text { 2006; Oppewal et } \\
\text { al., 2013; } \\
\text { Schramm, Swoboda, } \\
\text { \& Morschett, 2007; } \\
\text { Schröder \& Zharia, } \\
\text { 2008; Verhoef, } \\
\text { Neslin, \& Vroomen, } \\
\text { 2007; Yu et al.,2011 }\end{array}$ & $\begin{array}{l}\text { Chatterjee, 2010a; } \\
\text { Chatterjee, 2010b; } \\
\text { Chiange \& Li, 2010; } \\
\text { Chiu et al., 2011; } \\
\text { Choi \& Park, 2006; } \\
\text { Fernandez-Sabiote \& } \\
\text { Roman, 2012; } \\
\text { Kollmann et al., } \\
\text { 2012; Lueg et al., } \\
\text { 2006; Schramm et } \\
\text { al., 2007; Schröder } \\
\text { \& Zharia, 2008; } \\
\text { Toufaily et al., 2013; } \\
\text { Verhoef et al., } \\
\text { 2007; Yu et al., } \\
\text { 2011 }\end{array}$ & $\begin{array}{l}\text { Chiu et al., 2011; } \\
\text { Gensler et al., 2012; } \\
\text { Johnson et al., } \\
\text { 2006; Jones \& Kim, } \\
\text { 2010; J. Kim \& } \\
\text { Lee, 2008; Y. Kim, } \\
\text { Park, \& Pookulangara, } \\
\text { 2005; Kollmann et } \\
\text { al., 2012; Lee \& } \\
\text { Kim, 2008; Lu \& } \\
\text { Rucker, 2005; Piercy, } \\
\text { 2012; Schröder \& } \\
\text { Zharia, 2008; } \\
\text { Toufaily et al., 2013; } \\
\text { Verhoef et al., 2007 }\end{array}$ & $\begin{array}{l}\text { Chandrashekaran \& } \\
\text { Suri, 2012; } \\
\text { Chatterjee, 2010a; } \\
\text { Chatterjee, 2010b; } \\
\text { Chiange \& Li, 2010; } \\
\text { Chiu et al., 2011; } \\
\text { Fernandez-Sabiote \& } \\
\text { Roman, 2012; } \\
\text { Heitz-Spahn, 2013; } \\
\text { Lee \& Kim, 2008; Lu } \\
\text { \& Rucker, 2006; } \\
\text { Schramm et al., } \\
\text { 2007; Verhoef et al., } \\
\text { 2007; Yu et al., } \\
\text { 2011 }\end{array}$ \\
\hline $\begin{array}{l}\text { Factor } \\
(\mathrm{N})\end{array}$ & $\begin{array}{l}\text { Product knowledge } \\
(n=12)\end{array}$ & Experience $(n=10)$ & $\begin{array}{l}\text { Efficacy/Usefulness } \\
(n=7)\end{array}$ & Involvement $(n=7)$ \\
\hline Reference & $\begin{array}{l}\text { Bickle et al., 2006; } \\
\text { Chiange \& Li, 2010; } \\
\text { Cho \& Workman, } \\
\text { 2011; Gensler et al., } \\
\text { 2012; Heitz-Spahn, } \\
\text { 2013; Johnson et } \\
\text { al., 2006; Y. Kim et } \\
\text { al., 2005; Kollmann } \\
\text { et al., 2012; } \\
\text { Oppewal et al., } \\
\text { 2013; Schramm at } \\
\text { al., 2007; Verhoef et } \\
\text { al., 2007; Yu et al., } \\
\text { 2011 }\end{array}$ & $\begin{array}{l}\text { Bock et al., 2012; } \\
\text { Chiu et al., 2011; } \\
\text { Fernandez-Sabiote \& } \\
\text { Roman, 2012; } \\
\text { Frambach et al., } \\
\text { 2007; Gensler et } \\
\text { al., 2012; Hahn \& } \\
\text { Kim, 2009; Jones \& } \\
\text { Kim, 2010; J. Kim \& } \\
\text { Lee, 2008; Lu \& } \\
\text { Rucker, 2006; Piercy, } \\
2012\end{array}$ & $\begin{array}{l}\text { Bock et al., 2012; } \\
\text { Chiu et al., 2011; } \\
\text { Choi \& Park, 2006; } \\
\text { Frambach et al., } \\
\text { 2007; Hahn \& Kim, } \\
\text { 2009; J. Kim \& Lee, } \\
\text { 2008; Schröder \& } \\
\text { Zharia, } 2008\end{array}$ & $\begin{array}{l}\text { Cho \& Workman, } \\
\text { 2011; Johnson et } \\
\text { al., 2006; Jones \& } \\
\text { Kim, 2010; Lee \& } \\
\text { Kim, 2008; Lu \& } \\
\text { Rucker, 2006; Lueg } \\
\text { et al., 2006; Piercy, } \\
\text { 2012 }\end{array}$ \\
\hline $\begin{array}{l}\text { Factor } \\
(\mathrm{N})\end{array}$ & $\begin{array}{l}\text { Shopping } \\
\text { environment/situation } \\
\text { factors }(n=7)\end{array}$ & Demographics $(n=6)$ & Product types $(n=6)$ & $\begin{array}{l}\text { Social influence } \\
(n=3)\end{array}$ \\
\hline Reference & $\begin{array}{l}\text { Bock et al., 2012; } \\
\text { Fernandez-Sabiote \& } \\
\text { Roman, 2012; Jones } \\
\text { \& Kim, 2010; Lu \& } \\
\text { Rucker, 2006; } \\
\text { Oppewal et al., } \\
\text { 2013; Schramm et } \\
\text { al., 2007; Seock \& } \\
\text { Nortan, } 2007\end{array}$ & $\begin{array}{l}\text { Chandrashekaran \& } \\
\text { Suri, 2012: Cho \& } \\
\text { Workman, 2011; } \\
\text { Choi \& Park, 2006; } \\
\text { Johnson et al., } \\
\text { 2006; Joo \& Park, } \\
\text { 2008; Lueg et al., } \\
\text { 2006 }\end{array}$ & $\begin{array}{l}\text { Baal \& Dach, 2005; } \\
\text { Bickle et al., 2006; } \\
\text { Chiang \& Li, 2010; } \\
\text { Heitz-Spahn, 2013; } \\
\text { Kian \& Kim, 2006; } \\
\text { Piercy, } 2012\end{array}$ & $\begin{array}{l}\text { Bock et al., 2012; } \\
\text { Pookulangara et al., } \\
\text { 2011; Verhoef et al., } \\
2007\end{array}$ \\
\hline
\end{tabular}


Kim Soohyun - Ahn Insook / Challenge of Understanding Multichannel Customer Behavior in 21st Century

Convenience was the most frequently used predictive variable on multichannel choice $(n=17)$. Convenience refers to consumers' perception regarding easy access to information, and the amount of time and effort required in searching information (Chiang \& Li, 2010). Convenience factor is a frequently studied value or motive for shopping (Schröder \& Zharia, 2008). In their study, Schröder and Zharia (2008) reported that single-channel customers seek convenience during their decision process more than multichannel customers. The second most frequently-used variables were service (Chatterjee, 2010a; Chatterjee, 2010b; Chiange \& Li, 2010; Chiu, Hsieh, Roan, Tseng, \& Hsieh., 2011; Choi \& Park, 2006; Fernández-Sabiote \& Román, 2012; Kollmann et al., 2012; Lueg, Ponder, Beatty, \& Capella, 2006; Schramm, Swoboda, \& Morschett, 2007; Schröder \& Zharia, 2008; Toufaily, Souiden, \& Ladhari, 2013; Verhoef, Neslin, \& Vroomen, 2007; Yu, Niehm, \& Russell, 2011) and trust/risk (Chiu et al., 2011; Gensler, Verhoef, \& Böhm, 2012; Johnson et al., 2006; Jones \& Kim, 2010; J. Kim \& Lee, 2008; Y. Kim, Park, \& Pookulangara, 2005; Kollmann et al., 2012; Lee \& Kim, 2008; Lu \& Rucker, 2005; Piercy, 2012; Schröder \& Zharia, 2008; Toufaily et al., 2013; Verhoef et al., 2007). Saving money is the fourth most frequently used predictor variable for consumers' multichannel choices (Chatterjee, 2010a; Chatterjee, 2010b; Chiange \& Li, 2010; Lu \& Rucker, 2006; Schramm et al., 2007; Verhoef et al., 2007; Yu et al., 2011). Interestingly, apparel consumers may not mind spending time and money to purchase the product they want because they consider more hedonic aspects (Y. Kim, Park, \& Pookulangara, 2005). Also, price is not major predictor for online purchases (Fernández-Sabiote \& Román, 2012), for financial service products (Gensler et al., 2012), and in time-pressed situation (Heitz-Spahn, 2013; Oppewal, Tojib, \& Louvieris, 2013). The reason might be that today's Internet users may use new tools for price comparison in stores, and major retailers provide low price guarantee policies to their customers. Experience was another key influential variable for channel choice (Bock, Lee, Kuan, \& Kim, 2012; Chiu et al., 2011; Fernández-Sabiote \& Román, 2012; Frambach et al., 2007; Gensler et al., 2012; Hahn \& Kim, 2009; Jones \& Kim, 2010; J. Kim \& Lee, 2008; Lu \& Rucker, 2006; Piercy, 2012). Verhagen and van Dolen's study (2009) on online shopping intention showed that online service did not influence online shopping intention. This result may be because the studied items, CDs, are low-risk items and may not need services. Frambach et al. (2007) found that the channel usage intention for mortgage customer was moderated by the customer's Internet experience. Shopping environment and situation factors also influence consumers' channel choice. Shopping environment and situation factors are time pressure (Oppewal et al., 2013), internet connectivity (Fernández-Sabio te \& Román, 2012; Lu \& Rucker, 2006), website quality (Bock et al., 2012; Jones \& Kim, 2010; Seock \& Nortan, 2007), and quality of channel (Oppewal et al., 2013). Oppewal et al. (2013) demonstrate that time pressures force respondents to visit a travel agent or other channels to complete the purchase quickly.

\section{Demographic Variables}

This study presents a review of the findings regarding the relationship between multichannel customer demographics and multichannel behavior as presented in Table 3. The results are not consistent. Gender significantly 
Journal of Fashion Business Vol.18, No.3

influenced fashion innovativeness and opinion leadership (Cho \& Workman, 2011), but not multi-channel choice (Cho \& Workman, 2011; Heitz-Spahn, 2013). Choi and Park (2006) revealed that single-channel online channel purchasers are younger (ages of 10s) and more males with a higher education level than multichannel offline purchasers.

Attachment to the community influenced multichannel shopping in rural areas (Johnson et al., 2006). Joo and Park (2008) insisted that age is positive predictor for television channel choice and wealthy customers are inclined to use the catalog channel for purchasing. They also reported that customers who have jobs are not disposed to use the catalog for product purchasing, and more educated customers show propensity for TV channels but do not choose the catalog channel for product purchasing.
Even though findings show demographics positively related with channel choice, results may be different based on product types. Also, customers' Internet experience and multichannel research shopping and purchasing experience are extended to broader age groups. Customers' technology adoption rate is increasing, and their work environment is changing. Furthermore, consumers can easily connect to the Internet through smart phones and tablets during travel or at the beach. Those factors may change multichannel customers' purchasing behavior. As shown in the Table 3, only five studies dealt with demographics toward multichannel customer behavior and three studies (Chandrashekaran \& Suri, 2012; Cho \& Workman, 2011; Heitz-Spahn, 2013) are current, and their findings relationship between socio-demographics and multichannel choices are not consistent. In the case of teenagers,

Table 3. Demographics Factors

\begin{tabular}{|c|c|c|c|c|c|c|c|}
\hline \multirow{2}{*}{ Research } & \multirow{2}{*}{$\begin{array}{l}\text { Dependent } \\
\text { variable }\end{array}$} & \multicolumn{6}{|c|}{ Impact of demographics } \\
\hline & & Age & Gender & Income & Job & Education & Urbanicity \\
\hline $\begin{array}{l}\text { Chandrasheka-ran } \\
\text { and Suri (2012) }\end{array}$ & $\begin{array}{l}\text { Multichannel } \\
\text { choice }\end{array}$ & $\mathrm{NI}$ & $(+)$ & $\mathrm{Nl}$ & $\mathrm{Nl}$ & $\mathrm{NI}$ & $\mathrm{Nl}$ \\
\hline $\begin{array}{c}\text { Cho \& Workman } \\
(2011)\end{array}$ & $\begin{array}{l}\text { Multichannel } \\
\text { choice }\end{array}$ & $\mathrm{NI}$ & NS & $\mathrm{Nl}$ & $\mathrm{Nl}$ & $\mathrm{NI}$ & $\mathrm{NI}$ \\
\hline $\begin{array}{l}\text { Choi \& Park } \\
\text { (2006) }\end{array}$ & $\begin{array}{c}\text { Channel choice } \\
\text { behavior }\end{array}$ & $(+)$ & $(+)$ & $(+)$ & $\mathrm{Nl}$ & $(+)$ & $\mathrm{NI}$ \\
\hline $\begin{array}{c}\text { Johnson et al. } \\
\text { (2006) }\end{array}$ & $\begin{array}{l}\text { Multichannel } \\
\text { shopping } \\
\text { behavior }\end{array}$ & $\mathrm{Nl}$ & $\mathrm{Nl}$ & $\mathrm{Nl}$ & $\mathrm{Nl}$ & $\mathrm{NI}$ & $(+)$ \\
\hline $\begin{array}{l}\text { Heitz-Spahn } \\
\text { (2013) }\end{array}$ & $\begin{array}{l}\text { Multichannel } \\
\text { behavior }\end{array}$ & NS & NS & $\mathrm{Nl}$ & NS & $\mathrm{Nl}$ & $(+)$ \\
\hline Joo \& Park (2008) & Channel choice & $(+)$ & $\mathrm{NI}$ & $(+)$ & $(+)$ & $(+)$ & $\mathrm{NI}$ \\
\hline Lueg et al. (2006) & Channel choice & $\underset{(+)}{\text { Teenager }}$ & $\mathrm{Nl}$ & $\mathrm{Nl}$ & $\mathrm{Nl}$ & $\mathrm{Nl}$ & $\mathrm{Nl}$ \\
\hline
\end{tabular}

(NI: Not Investigated, NS: Not Significant, +: Positive Relationship) 
their shopping channel choices are influenced by channel involvement (Lueg et al., 2006). In some studies, customers showed significantly different purchasing behavior by gender, age (Bendoly, Blocher, Bretthauer, Krishnan, \& Venkataramanan, 2005; Chatterjee, 2010a), and education (Chatterjee, 2010a), but demographics were not analyzed in those studies.

\section{Social Influence}

Multichannel offline customers perceived the Internet and family/friends as most important for information sources, as compared to multichannel online customers (Choi \& Park, 2006). Normative beliefs influenced significantly, but negatively, on subjective norm toward channel migration for brick-and-mortar stores and catalogs. It may be that college students are mainly part of the social media generation and therefore are easily influenced by social network opinion (Pookulangara, Hawley, \& Xiao, 2011). In addition, Bock et al. (2012) found word-of-mouth (WOM) is a predictor of channel choice.

\section{Product Types}

Product features such as style, shape, and color in catalogs are significant predictors of purchasing behavior in home décor items. Product rarity at brick-and-mortar stores is also a significant predictor of purchasing behavior in home décor products (Bickle, Buccine, Makela, \& Mallette, 2006). Bock et al. (2012) found that with increases in product uncertainty, the effects of WOM, offline trust, and efficacy of sanctions on online trust are greater for experience products than for search products. Chiang and Li (2010) insisted that the most important factors affecting consumers' channel preference for books and CDs are price, convenience, and product variety. For electronics, product variety, price, and service provided are the most important criteria. For fashion goods, accessibility, quality, and product variety are the most important.

\section{Beyond Determinants}

The aims of this study did not include analyzing channel integration, cross-cultural study, or cross channel and free-riding tendency to competitors' channels. However, in discussing future research recommendations, this study would like to briefly mention on those aspects.

Channel integration

Perceived integration is associated with a reduced likelihood of firm switching upon initial channel failure (Bendoly et al., 2005). However, perceived multichannel integration does not significantly influence on within-firm lock-in (Chiu et al., 2011). This may be because many multichannel retailer functions are still not relatively integrated. Verhoef et al. (2007) argued that the Internet had little lock-in compared to stores and found that catalog customers are inclined to search catalogs and purchase Internet patterns. While another study found that all in-home shopping had considerable lock-in, no cross-channel synergy was found between in-home channels (Joo \& Park, 2008). The different results might be brought because the studies were conducted in different countries, and compared channels for the studies were different.

\section{Cross-cultural Research}

Culture represents a shared set of values that 
influence social beliefs, attitudes, intention, and actual behavior (Zhou, Dai, \& Zhang, 2007). Lu and Rucker (2006) studied cross-cultural research with the intention of using multiple channels based on consumers' characteristics. The team found that innovation in preference for shopping is positively related to convenience orientation and Internet connectivity in China, but is negatively related to age in the US.

Channel-switching tendency and free riding to competitor's channels

When consumers employ more than one channel within a single transaction, they can obtain services from retailer $A$ and place their business with retailer $B$, engaging in free riding of competitors. Other customers, however, may be inclined to stay with the same retailer, even when they switch channels. van Baal and Dach (2005) found that over $20 \%$ of consumers are free riders, and that retailers retain substantially fewer customers. Chiu et al. (2011) found that $64 \%$ of research shoppers are cross-channel free riders. The research found that free riding on the services provided online is likely for products with dominant search characteristics, rapid technological changes, and a low frequency of purchases (Van Baal \& Dach, 2005). Two of the reviewed studies (Chatterjee, 2010a; Chatterjee, 2010b) assessed online order pickup store (OOPS) to find influences on channel choice. Consumers with shorter purchase horizons are less likely use OOPS then those with longer purchase horizons. Also, more price-conscious customers are more likely to use OOPS. Purchase size, purchase deferral, and repurchase intentions are higher at the retailers offering OOPS (Chatterjee, 2010a). Retailer satisfaction, unplanned purchasing, and sizes of purchase orders are higher for cross-channel retailers (Chatterjee, 2010b).

\section{Conclusion}

The purpose of this study is, first, to provide comprehensive reviews of studies of multichannel consumer behaviors published in peer reviewed academic journals from 2005 to 2014. Second, this study is to develop a conceptual framework that demonstrates multichannel determinants such as psychographics, demographics, social influences, and situational factors on consumers' search and purchase behavior based on customers' benefits or costs judgment. Finally, this study is to provide possible future research direction in multichannel consumer behavior.

To achieve these aims, three steps were taken in the process of analyzing consumers' channel determinants presented in the 37 studies. First, a total of 70 factors/determinants used in the various studies were extracted from the text of the papers and were re-sorted into 15 categories, which were further condensed to twelve most-used factors that appear in the studies. These factors are convenience, product knowledge, service, product types, trust/risk, involvement, experience, saving money, shopping environment/situation factors, efficacy/usefulness, social influence, and demographics. With 12 determinants of multichannel consumers' search and purchase behavior, a conceptual framework was proposed based on expectancy theory, which posits that an individual behaves in a certain way because the or she links particular utilities to product or service attributes so that he or she selects a specific behavior over other behavior.

This meta-analysis covered research with only primary data, not dealing with studies containing only secondary data sources. Therefore, it was impossible to access actual purchase and 
multichannel customer behavior after sales. Also, 14 out of 37 studies got data from student samples. This sampling practice limited generalized analysis of multichannel customer behavior.

For future study, some studies analyzed relationships between socio-demographics and channel choices, but results did not show consistency. Therefore this area should be investigated further. Another significant question is whether or not customers across the continents and countries show similar behavior or not? Answering this question will be critical to global retailers. Global companies must understand customers in different countries to gain global market share; however, only one study dealt with cross cultural analysis. Therefore, cross-cultural multichannel behavioral analysis is recommended. Finally because of advanced technology, recent customers receive promotional message via their mobiles. They visit a store to check and compare the price of the product they want to purchase inside of the store. Eventually they purchase it through online. It means that showrooming is a big trend now. To overcome free riding behavior, multichannel retailers are integrating their marketing mix with better services such as OOPS (order online and pay at the store), store locator, return to store policy, and price matching services. These options let web based buyers avoid added shipping costs, lead time to receive products, and risks. Those services may lead customers to have positive attitudes toward multichannel retailers and result in customer satisfaction and loyalty. Therefore, it will be helpful to study how retailers' service choices elicit trust and satisfaction.

\section{References}

Bendoly, E., Blocher, J., Bretthauer, K., Krishnan, S., \& Venkataramanan, M. (2005). Online/In-Store Integration and Customer Retention. Journal of Service Research, 74), 313-327.

Bickle, M. C., Buccine, R., Makela, C. J., \& Mallette, D. (2006). Consumers' uniqueness in home décor: Retail channel choice behavior. International Review of Retail, Distribution \& Consumer Research, 16(3), 317-331.

Bock, G., Lee, J., Kuan, H., \& Kim, J. (2012). The progression of online trust in the multi-channel retailer context and the role of product uncertainty. Decision Support Systems, 53(1), 97-107

Burt, S., \& Sparks, L. (2003). E-commerce and the retail process: A review. Journal of Retailing and Consumer Service 10, 275-286.

Carlson, K. A., Janiszewski, C., Keeney, R. L., Krantz, D. H., Kunreuther, H. C., Luce, M. F., \& Von Winterfeldt, D. (2008). A theoretical framework for goal-based choice and for prescriptive analysis. Marketing Letters, 19(3-4), 241-254.

Chandrashekaran, R., \& Suri, R. (2012). Effects of gender and price knowledge on offer evaluation and channel transition in retail and e-tail environments. Journal of Product \& Brand Management, 21(3), 215-225.

Chatterjee, P. (2010a). Causes and consequences of 'order online pick up in-store' shopping behavior. International Review of Retail. Distribution \& Consumer Research, 20(4), 431-448.

Chatterjee, P. (2010b). Multiple-channel and cross-channel shopping behavior: Role of consumer shopping orientations. Marketing Intelligence \& Planning, 28(1), 9-24. 
Chiang, W., \& Li, Z. (2010). An analytic hierarchy process approach to assessing consumers' distribution channel preference. International Journal of Retail \& Distribution Management, 38(2), 78-96.

Chiu, H.-C., Hsieh, Y.-C., Roan, J., Tseng, K.-J., \& Hsieh, J.-K. (2011). The challenge for multichannel services: Cross-channel free-riding behavior. Electronic Commerce Research and Applications, 10(2), 268-277.

Cho, S., \& Workman, J. (2011). Gender, fashion innovativeness and opinion leadership, and need for touch: Effects on multi-channel choice and touch/non-touch preference in clothing shopping. Journal of Fashion Marketing \& Management, 15(3), 363-382.

Choi, J., \& Park, J. (2006). Multichannel retailing in Korea: Effects of shopping orientations and information seeking patterns on channel choice behavior. International Journal of Retail \& Distribution Management, 34(8), 577-596.

European consumer views of E-commerce: A consumer research study of buying behavior and trends, White paper. (2011). Oracle Corp. Retrieved May 15, 2014, from http://www.oracle.com/us/products/application s/atg/euro-commerce-survey-333316.pdf

Fernández-Sabiote, E., \& Román, S. (2012). Adding clicks to bricks: A study of the consequences on customer loyalty in a service context. Electronic Commerce Research and Applications, 11(1), 36-48.

Frambach, R., Roest, H., \& Krishnan, T. (2007). The impact of consumer Internet experience on channel preference and usage intentions across the different stages of the buying process. Journal of Interactive Marketing, 21(2), 26-41.

Gefen, D., Benbasat, I., \& Pavlou, P. (2008). A research agenda for trust in online environments. Journal of Management Information Systems, 24(4), 275-286.

General information. HSN (2014). Retrieved May 15, 2014 from http://www.hsni.com/ cornerstone.cfm

Gensler, S., Verhoef, P. C., \& Böhm, M. (2012). Understanding consumers' multichannel choices across the different stages of the buying process. Marketing Letters, 23(4), 987-1003.

Hahn, K., \& Kim, J. (2009). The effect of offline brand trust and perceived internet confidence on online shopping intention in the integrated multi-channel context. International Journal of Retail \& Distribution Management, 37(2), 126-141.

Hamilton, Chernev, A., \& Chernev, R. (2010). Managing product assortments: Insights from consumer psychology. In in Kellogg on marketing, in Tybout, A. \& Calder, B. (Eds.), Kellogg on marketing, (2nd ed.). New York, NY: Wiley.

Heitz-Spahn, S. (2013). Cross-channel free-riding consumer behavior in a multichannel environment: An investigation of shopping motives, sociodemographics and product categories. Journal of Retailing and Consumer Services, 20(6), 570-578.

Is that deal really a deal? Use the price check by Amazon app to make sure, Press Release, (2011). Amazon.com Inc. Retrieved May 15, 2014 from http://phx.corporate-ir.net

Jones, C., \& Kim, S. (2010). Influences of retail brand trust, off-line patronage, clothing involvement and website quality on online apparel shopping intention. International Journal of Consumer Studies, 34(6), 627-637. Johnson, K., Yoo, J., Rhee, J., Lennon, S., Jasper, C., \& Damhorst, M. (2006). Multi-channel shopping: Channel use among 
rural consumers. International Journal of Retail \& Distribution Management, 34(6), 453-466.

Joo, Y., \& Park, M. (2008). Information search and purchase channel choice across in-home shopping retail formats. Academy of Marketing Studies Journal, 12(2), 49-61.

Kim, J., \& Lee, H. (2008). Consumer product search and purchase behavior using various retail channels: The role of perceived retail usefulness. International Journal of Consumer Studies, 32(6), 619-627.

Kim, Y., Park, S., \& Pookulangara, S. (2005). Effects of multi-channel consumers' perceived retail attributes on purchase intentions of clothing products. Journal of Marketing Channels, 12(4), 23-43.

Kollmann, T., Kuckertz,A., \& Kayser, I. (2012). Cannibalization or synergy? Consumers' channel selection in online-offline multichannel systems. Journal of Retailing \& Consumer Services 19(2), 186-194.

Lee, H., \& Kim, J. (2008). The effects of shopping orientations on consumers' satisfaction with product search and purchases in a multi-channel environment. Journal of Fashion Marketing and Management, 12(2), 193-216.

Levy, M., \& Weitz, B. (2009). Retailing management (7th ed.). New York, NY: The McGraw-Hill/Irwin Companies Inc.

Lu, Y., \& Rucker, M. (2006). Apparel acquisition via single vs. multiple channels: College students' perspectives in the US and China. Journal of Retailing \& Consumer Services, 13(1), 35-50.

Lueg, J. E., Ponder, N., Beatty, S. E., \& Capella, M. L. (2006). Teenagers' use of alternative shopping channels: A consumer socialization perspective. Journal of Retailing, 82(2), 137-153.
Mobile shopping doubles over December 2011 holiday, IBM Corp. Press Release, (2012). Retrieved May 15, 2014, from http://www-03.ibm.com/press/us/en/pressrelea se/36472.wss.

Murphy, P. (2000). Clicks vs. bricks' data helps retailers develop multi-channel customer strategy. Stores Magazine, 82(9), 168.

Oliver, R. L. (1974). Expectancy theory predictions of salesmen's performance. Journal of Marketing Research, 11(3). 243-253.

Oppewal, H., Tojib, D. R., \& Louvieris, P. (2013). Experimental analysis of consumer channel-mix use. Journal of Business Research, 66(11), 2226-2233.

Piercy, N. (2012). Positive and negative cross-channel shopping behavior. Marketing Intelligence \& Planning, 30(1), 83-104.

Pookulangara, S., Hawley, J., \& Xiao, G. (2011). Explaining multi-channel consumer's channel-migration intention using theory of reasoned action. International Journal of Retail \& Distribution Management, 39(3), 183-202.

Rosenberg, M. J. (1956). Cognitive structure and attitudinal affect. The Journal of Abnormal and Social Psychology, 53(3), 367-372.

Scally, R. (2000). Clicks-and-mortars have right stuff to dominate the Internet. Discount Store News, 39(2), 4.

Schramm, H., Swoboda, B., \& Morschett, D. (2007). Internet vs. brick-and-mortar stores analyzing the influence of shopping motives on retail channel choice among internet users. Journal of Customer Behavior, 6(1), 19-36.

Schröder, H., \& Zaharia, S. (2008). Linking multi-channel customer behavior with shopping motives: An empirical investigation of a German retailer. Journal of Retailing \& Consumer Services, 15(6), 452-468. 
Seock, Y., \& Norton, M. (2007). Attitude toward internet web sites, online information search, and channel choices for purchasing. Journal of Fashion Marketing \& Management, 11(4), 571-586.

Stone, M., Hobbs, M., \& Khaleeli, M. (2002). Multichannel customer management: The benefits and challenges. Journal of Database Management 10(1), 39-52.

Toufaily, E., Souiden, N., \& Ladhari, R. (2013). Consumer trust toward retail websites: Comparison between pure click and click-and-brick retailers. Journal of Retailing and Consumer Services, 20(6), 538-548.

U.S. Census Bureau. (2014). Monthly \& annual retail trade. Retrieved May 20, 2014, from http://www.census.gov/retail/

van Baal, S., \& Dach, C. (2005). Free riding and customer retention across retailers' channels. Journal of Interactive Marketing, 19(2), 75-85.

Verhagen, T., \& van Dolen, W. (2009). Online purchase intentions: A multi-channel store image perspective. Information \& Management, 46(2), 77-82.

Verhoef, P., Neslin, S., \& Vroomen, B. (2007). Multichannel customer management: Understanding the research-shopper phenomenon. International Journal of Research in Marketing, 24(2), 129-148.

Walker, B. (2011, March 14). Why multichannel retail is obsolete. Forbes. Retrieved from http://www.forbes.com/2011/03/11/multi-chan nel-touchpoint-leadership-sales-leadership-ob solete.html

Yu, U., Niehm, L., \& Russell, D. (2011). Exploring perceived channel price, quality, and value as antecedents of channel choice and usage in multichannel shopping. Journal of Marketing Channe/s, 18(2), 79-102.
Zhou, L., Dai, L., \& Zhang, D. (2007). Online shopping acceptance model: A critical survey of consumer factors in online shopping. Journal of Electronic Commerce Research, 8(1), 41-62.

Received (November 18, 2013)

Revised (June 4, 2014; July 8, 2014)

Accepted (July 11, 2014) 